\title{
Geographical Studies and Teaching
}

\section{Geographical Association}

$\mathrm{T}$ E annual meeting of the Geographical Associa. tion was held at the London School of Economics on January 2-5. Lord Meston in his presidential address dealt with the "Geography of an Indian Village", referring particularly to his own experience as a settlement officer in the United Provinces in the early days of his service in the Indian Civil Service.

This careful description of the work of a settlement officer has a great importance as illustrating the use of a thorough local geographical study as a basis for property valuation, taxation and local administration. When the assessment or reassessment of a District (using that term in its Indian sense as meaning an administrative unit, commonly 1,0003,000 square miles in area) becomes necessary, the work, which is likely to occupy three or four years, is entrusted to a 'settlement officer'. He starts by securing a general view of the whole area, and in the careful descriptions prepared there exists, hidden away in Government offices throughout India, a vast store of unpublished material of great geographical value. He then undertakes systematically the survey of each village- -a 'village' designating the tract of land (in the United Provinces commonly 50-1,000 acres) round the hamlet or residential centre. A base map-usually on the scale of 16 inches to one mile-is prepared either by the Survey of India or by an ad hoc survey party controlled by the settlement officer. Each field is numbered and a description of it made by the village accountant. The record includes the character of the soil, crops, ownership, occupation, taxable value and taxes paid. The soil classification commonly used is into black cotton soil, first-class loam, second-class loam, sandy loam, sand, gravel and uncultivable. It is not perhaps fully realised that there exists for practically the whole of settled India this accurate soil and land utilisation survey.

The nucleus of the older type of Indian village in the United Provinces is usually the ancestral home of the chief landowner surrounded by its mud wall. Around it is an irregular ring of houses-arranged with very little planning and no sanitation; then the hovels of the depressed classes. The village pond, which serves as a public bath for man and beast as well as for a supply of drinking water, completes the picture. Surrounding the hamlet is a ring of richly manured land but which, because of the source of its manure, is only cultivated by the depressed classes, and then finally the arable land of the villagers. Reference was made by Lord Meston to changes in soil and soil values which are tending to result from the extension of irrigation-including the impoverishment consequent upon the accumulation of alkali.

Two sessions of the Association were held in conjunction with the Le Play Society. At one, Mr. A. E. Moodie gave an account of studies carried out in the Stubaital in the Austrian Tyrol. At the other, under the chairmanship of Sir John Russell, the leader of the party in the field, three short papers were presented on Russia. Mr. R. A. Pelham gave a historical introduction, Dr. A. S. J. Baster, an economist's view, while Mr. Leonard Brooks gave a fascinating account of recent educational developments. He emphasised the central place that the factory occupies in the life of a community and that, like other activities, the school is attached to it. As vocational education, the system is good in the essentially close contact which is maintained. The children are given a conspectus of the whole working of the factory, and can afterwards take their places in different parts of the works. Similarly, the university has almost entirely given place to specialised technical research or training institutions. There are already signs, it would appear, of the desire to return to a more general educational system, at least in places, but the general progress in literacy made in the last five years is so amazing as to be almost incredible.

Dr. G. P. Gooch in his address on "Geography and International Problems" indicated clearly the importance attached by historians to the geographical background, but at the same time illustrated the need for closer co-operation between specialists. His sketch of the geographical background of China could not possibly be accepted by geographers, nor could his description of the Saar.

Dr. Dudley Stamp in his lecture on "Planning the Land for the Future" referred particularly to recent studies in land utilisation in the United States. At present, out of a total area of $3,000,000$ square miles, the proper use of roughly a third is not yet decided. For the best types of land in the country-for example, the belts of good soil in the Middle West-. it is clear that they must remain in agriculture. Similarly, for the poorest lands the proper use is clearly desert, forest or grazing. The problems arise in areas of intermediate value. Amongst the reasons for existing mal-utilisation of land $\operatorname{som} \theta$ of the chief are: $(a)$ those consequent upon the history of settlement - the clearing of poor land in the East before the better land was discovered; $(b)$ the ravages of soil erosion; (c) the development of communications throwing all areas into ready contact and rendering cultivation in poorer tracts uneconomic ; $(d)$ 'overproduction' of agricultural commodities consequent upon technical progress combined with diminution of foreign trade; (e) the depletion of forest lands; and $(f)$ social changes-the need for more land for recreation or for semi-subsistence cultivation. A summary was given of work undertaken, especially under the Roosevelt administration, to combat the difficulties. Of the varied planning schemes, those based on the economic needs of the moment are fraught with danger; those based on a careful investigation of the potential capacities of the land are working on a sure foundation.

Among the interesting lectures of a general nature must be mentioned that by Brigadier H. St. J. L. Winterbotham on the history of the Ordnance Survey, Dr. Bernard Smith on water supply and Dr. Allen Mawer on place name study.

\section{INSTITUTE OF BRITISH GeOgRaphers}

The formation of the Institute of British Geographers was recorded in NATURE of January 14, 1933, and the Institute held its third annual meeting at the London School of Economics on January 1 and 4 of this year.

Dr. H. A. Matthews dealt with the "Seasonal Distribution of Rainfall in the Mediterranean Region of California" by a careful analysis of dispersion 
diagrams. The results, in this area, confirm the general simplicity of the regime and do not therefore add greatly to the information obtained by using mean monthly rainfall values, but a clear demonstration is afforded of the value of a logarithmic scale in plotting seasonal variation. Variability of monthly precipitation increases markedly $(a)$ from north to south and $(b)$ from lower to higher elevations.

Mr. E. G. Bowen showed the results of attempting to map the 'spheres of influence' of the missionary saints of the Dark Ages, choosing St. Samson and St. Columba, in Celtic Britain. These spheres seem to coincide with cultural provinces determined on the basis of archæological distributions, but in the discussion various reasons were suggested for this. Mr. K. H. Huggins's paper on "Types of Settlement in the Scottish Highlands" was concerned to a considerable degree with the delimitation of the 'Highlands' as distinct from the 'Lowlands'. By using such criteria as structure, elevation, 'amount of relief', proportion of moorland, type and density of settlement, different 'limits' to the Highlands are obtained, and there is clearly a central area where all the Highland characteristics are present, fringed by a broad transitional area.

Mr. K. C. Edwards dealt with the consequences of recent improvements in the River Trent as a waterway--including the growth of Nottingham as a leading distribution centre for petroleum products.

The distribution of settlements, permanent and temporary, and of cultivated crops in Alpine valleys, is a subject of considerable importance and concerning which there is an extensive literature. But an important advance in knowledge is marked by Miss Alice Garnett's careful and suggestive study of insolation. A formula for the calculation of insolation intensity at any given spot (based on slope, aspect and the sun's elevation) has been devised and it is possible to construct 'intensity maps'. Special importance is attached to spring noonday intensity values. At the same time 'time periods of insolation' are mapped and the results are combined.
This method of investigation seems to demonstrate a possible law of alpine settlements, namely, that above c. 1,100 m., all permanent settlements avoid the areas of winter shade, while ubac villages follow the edge of the winter noonday shadow line. For regions studied in lat. $46^{\circ} \mathrm{N}$., above $1,400 \mathrm{~m}$., wheat, barley and rye require at least an $80-90$ per cent spring noonday intensity. Wheat can ripen up to c. $1,600 \mathrm{~m}$. where a noonday equinox intensity exceeds 90-95 per cent of the maximum possible at that time, provided these areas also have long time periods of insolation. Areas with a 50-70 per cent intensity are generally given over to meadow, while land with an intensity value of less than 50 per cent is left to forest. It is abundantly clear that this study has an important bearing on land planning in alpine areas and is capable of extension to regions of lower relief in higher latitudes-for example, to the Highland valleys of Scotland and Antrim, where the intensity and time period of insolation would seem to have a bearing on health problems.

Dr. S. W. Wooldridge, by a preliminary analysis of areas in the London basin, dealt with the 'facet' as the ultimate unit of geographical analysis. The facet is difficult of definition though the concept is clear. A river terrace, a dip slope, a plateau (even if only a fragment) are 'facets' which thus correspond in general with geomorphological units, but in detail have different boundaries. Thus the 'Taplow Terrace facet' as a geographical unit does not coincide with the distribution of the Taplow Terrace gravels of the geological map.

The last session of the meeting was devoted to a discussion of Prof. C. B. Fawcett's paper on the relations between the advance of science in geography and the life of the community, read before the British Association at Aberdeen in September last.

The Institute, in accordance with its avowed policy of publishing memoirs too long for inclusion in existing periodicals but unsuitable for publication in book form, has issued, as its first volume, Dr. R. O. Buchanan's study of the pastoral industries of New Zealand.

L. Dudley Stamp.

\section{Annual Meeting of the}

$\mathrm{T}$ HE annual meeting of the Mathematical Association was held at the Institute of Education, London, W.C.1, on January 7-8, under the presidency of Prof. E. H. Neville, of the University of Reading. The following distinguished mathematicians were elected honorary members of the Association: Profs. E. Borel (Paris), J. Hadamard (Paris), G. H. Hardy (Cambridge), D. E. Smith (New York), E. T. Whittaker (Edinburgh). Mr. A. W. Siddons, of Harrow School, was elected president of the Association for the fortheoming year.

In his presidential address, entitled "The Food of the Gods", Prof. Neville dealt with a problem in mathematical education which is of considerable importance and difficulty. From the fact that the preparation given to a schoolboy a quarter of a century ago for an entrance scholarship examination at Cambridge would be adequate to this examination as it is at present, while the undergraduate of those days would find many of the questions in a modern tripos incomprehensible, he deduced that the universities of to-day build a different mathematical structure, but are content to build it on foundations which have not changed since the beginning of the

\section{Mathematical Association}

century. Since this difference is due to the direct influence of changes in emphasis in creative mathematics on the teaching at the universities, he urged that such changes ought to have a greater and far more rapid influence on teaching at the schools than they seem to have. Room for new ideas can only be found by omissions or condensations, by the expulsion from the curriculum of methods and ideas once valuable but now outworn, kept in place through inertia. To demonstrate the possibility of such a reform, Prof. Neville gave some examples illustrating the successful working of a similar process at the undergraduate stage. To bring this about at the school stage, the young teacher has the knowledge of what is important, the old teacher has the experience of what is practicable and the influence to effect the changes he desires, and Prof. Neville sees in this an opportunity for the generations to co-operate. At present, each advance is followed by a score of years in which the backward schools and the popular textbooks creep up to the leaders ; he envisages a responsiveness everywhere to the ferment of current ideas, which should re. sult in a mathematical nourishment requiring no long periods of accommodation, the true 'food of the gods'. 